\title{
Langkah Mudah Meluncurkan Startup Edukasi
}

\author{
NUR KUSUMAWATI \\ Universitas Nahdlatul Ulama Sidoarjo
}

\section{Pengantar}

Ada banyak peluang bagi pendatang baru di industri pendidikan dengan bidang keahlian baru dan klaim keberhasilan yang lebih besar. Dunia wirausaha menjadi trendi (Purnomo et al., 2019) karena masyarakat membutuhkan kewirausahaan (Setyawati, Purnomo, Irawan, Tamyiz, \& Sutiksno, 2018). Pendidikan Indonesia membutuhkan peningkatan akses, mutu dan relevansi pendidikan untuk memberi manfaat membangun bagi pendidikan dan rakyat Indonesia (Irawan et al., 2018).

\section{Panduan Langkah Startup Edukasi}

Berikut adalah panduan singkat langkah demi langkah untuk meluncurkan rintisan wirausaha ke pasar pendidikan online. Bagaimana cara Anda dapat memulai bisnis edukasi Anda sendiri.

\section{Co-founders Sangat penting}

Untuk menjalankan startup pendidikan Anda secara efektif, cari orangorang yang cukup baik untuk menjadi co-founder bisnis Anda. Itu penting untuk mendapatkan dukungan finansial dan emosional pada berbagai tahap awal startup. Co-founder akan membagikan kekhawatiran Anda dan mencoba menawarkan solusi kepada Anda ketika bisnis tidak berjalan dengan baik. Namun demikian, para pendiri harus rukun dan mendukung bisnis Anda dengan mudah setiap saat (Ray, 2015). Manajemen adalah proses mengarahkan atau menjalankan bisnis, serta. sekelompok manajer atau direktur (Purnomo, Putri, \& Rosyidah, 2017).

\section{Rencanakan Pelajaran Anda}

Dengan gagasan suku dan batu penjuru Anda, Anda dapat mulai merencanakan pelajaran pertama yang akan Anda ajarkan. Sebelum Anda meluncurkan, praktik yang baik untuk memiliki setidaknya satu pelajaran yang "bisa diselesaikan" untuk setiap ide landasan Anda. Ini adalah bagian yang bisa mereka mulai, selesaikan, dan pelajari sebelum pindah ke topik lain. Tetap menggunakan contoh desain grafis di atas, tiga video pertama Anda mungkin terlihat seperti (Johnson, 2019):

- Penelitian: Cara menemukan klien potensial di Linkedln

- Penjangkauan: Cara membuat email pitch yang sempurna

o Penjualan: Cara menjual ke klien di telepon. 
Anda mungkin juga ingin menambahkan tambahan untuk pelajaran ini. Anda dapat memasukkan PDF, trek audio, mencetak lembaran dan apa pun yang Anda rasa akan menambah kedalaman pelajaran. Sekarang, penting untuk dicatat bahwa Anda tidak perlu memiliki sekolah "selesai" pada saat diluncurkan. Keindahan menjalankan sekolah seperti ini adalah Anda dapat menyesuaikan, menambah, dan mengubah konten Anda berdasarkan umpan balik siswa Anda. Jika Anda mendaftarkan siswa, mereka menonton video, dan mereka berteriak untuk informasi lebih lanjut tentang topik tertentu, Anda sebaiknya memenuhi kebutuhan mereka. Gagasan pada awalnya adalah memiliki cukup konten yang menurut mereka layak mendapatkan nilai uang mereka, tetapi cukup beragam mereka tahu ini bukan kursus rata-rata Anda (Johnson, 2019). Industri era 4.0 membutuhkan metode pembelajaran kekinian (Sudrajat et al., 2019).

\section{Identifikasi target pasar}

Pendidikan adalah menyampaikan ilmu dan mentransformasi orang lain menjadi lebih baik (Fidiana, Istiana, Rosyidah, \& Purnomo, 2017). Kenali pasar Anda yang ingin dicapai dengan bisnis kecil terkait pendidikan Anda. Anda dapat memilih untuk menawarkan kursus persiapan perguruan tinggi kepada siswa sekolah menengah atas atau layanan bimbingan belajar untuk siswa sekolah menengah. Memahami target pasar Anda akan membantu Anda mencari tahu di mana dan bagaimana cara beriklan (Brookins, 2019). Siswa perlu memahami apa yang diketahui dan apa yang diminta untuk memiliki kemampuan menjawab (Suci et al., 2018).

\section{Buat kursus pertama Anda}

Kursus yang lebih panjang secara teori dengan informasi yang lebih berharga akan menyamakan dengan produk yang lebih berharga, dan yang lebih mudah menonjol dari kerumunan. Tapi ini belum tentu apa yang orang inginkan dari kursus, terutama yang online. Banyak orang yang mencari perbaikan diri mencari perbaikan cepat; cara untuk belajar di istirahat makan siang dan membuat kemajuan yang mantap dan nyata. Meskipun ini bukan cara pembelajaran secara umum, ada beberapa cara yang dapat Anda lakukan untuk mengakomodasi gaya belajar ini. Yang paling mudah adalah dengan menahan beberapa detail. Turunkan kursus pertama Anda ke esensinya, dan sertakan detail yang paling relevan untuk menyampaikan pendapat Anda dan mengajari siswa Anda hal-hal yang perlu mereka ketahui. Setelah mereka mengambil kursus pertama, Anda kemudian dapat menawarkan mereka kursus lebih lanjut yang memberikan tingkat kedalaman dan wawasan yang lebih besar pada beberapa topik yang sama. Ini akan mencegah orang dari dimatikan oleh kursus yang sangat panjang atau kompleks, dan memberi Anda ruang gerak ketika datang untuk memperluas 
layanan Anda. Berhati-hatilah untuk memberi harga kursus dengan benar (Eurostart Entreprises, 2015). Penerapan pembelajaran multimedia dapat meningkatkan prestasi siswa; dan tes menunjukkan bahwa prestasi belajar siswa kelas belajar multimedia lebih baik daripada siswa kelas konvensional (Iskandar, Rizal, Kurniasih, Sutiksno, \& Purnomo, 2018). Teknologi komputer telah menawarkan peluang baru dalam proses pembelajaran baik di ruang kelas, pembelajaran jarak jauh atau belajar mandiri (Simarmata et al., 2018).

\section{Menentukan Kepemilikan Bisnis}

la harus mengadopsi model tertentu di mana bisnis akan beroperasi ketika seseorang mulai dengan bisnis,. Dalam hal bisnis baru, ada dua cara untuk mendapatkan entri di industri: baik dengan menjadi startup atau dengan membeli waralaba. Dalam sebuah startup, operasi bisnis sepenuhnya terserah pemilik, dan kekuatan pengambilan keputusan juga ada di tangan pemilik. Sementara dalam model waralaba, Anda harus membeli waralaba dari perusahaan yang sudah ada dan Anda akan membantu dalam mengembangkan bisnis mereka. Dalam waralaba, kekuasaan tunggal tetap pada pemilik waralaba dan pewaralaba memiliki kekuatan tetapi terbatas. Jika Anda kekurangan modal yang diperlukan untuk menyiapkan bisnis baru, maka waralaba dapat membantu (Arya, 2019). Prinsip pendidikan adalah sosial. Sebagai seorang guru, kita harus memiliki kepedulian sosial (Asitah, Usmawati, Rosyidah, \& Purnomo, 2017).

\section{Penutup}

Langkah mudah meluncurkan startup edukasi adalah pentingnya cofounders, rencana pelajaran, identifikasi target pasar, buar kursus dan menentukan kepemilikan bisnis.

\section{References}

Arya, N. (2019). Things to Consider While Starting an Educational Services Business. Retrieved December 5, 2019, from https://www.franchiseindia.com/education/things-to-consider-while-starting-aneducational-services-business. 12980

Asitah, N., Usmawati, D. Z., Rosyidah, E., \& Purnomo, A. (2017). MI Hasyim Asy'ari IImu Harus Terus Mengarus. In Wirausaha Pendidikan Indonesia (Jilid 2). Sidoarjo: UNUSIDA Press.

Brookins, M. (2019). How to Start an Education Related Small Business. Retrieved December 6, 2019, from https://smallbusiness.chron.com/start-educationrelated-small-business-2239.html

Eurostart Entreprises. (2015). How to start an online education business. Retrieved December 7, 2019, from https://www.eurostartentreprises.com/businessadvice/item/194-how-to-start-an-online-education-business 
Fidiana, W., Istiana, Z., Rosyidah, E., \& Purnomo, A. (2017). MINU Waru 2 Insan Berkilau Cahaya Manfaat. In Wirausaha Pendidikan Indonesia (Jilid 4).

Sidoarjo: UNUSIDA Press.

Irawan, D. E., Purnomo, A., Sutiksno, D. U., Abraham, J., Alamsyah, A., Saputra, D. H., ... Rosyidah, E. (2018). Kajian Pendidikan Tinggi IDRI untuk DPR RI dan Ristek Dikti 2018. Bandung: ITB Press.

Iskandar, A., Rizal, M., Kurniasih, N., Sutiksno, D. U., \& Purnomo, A. (2018). The Effects of Multimedia Learning on Students Achievement in Terms of Cognitive Test Results. Journal of Physics: Conference Series, 1114(1), 012019. https://doi.org/10.1088/1742-6596/1114/1/012019

Johnson, J. (2019). How to Start a Profitable Online School in 5 Easy Steps.

Retrieved December 6, 2019, from https://www.uscreen.tv/blog/how-to-startcreate-online-school/

Purnomo, A., Asitah, N., Rosyidah, E., Septianto, A., Daryanti, M. D., \& Firdaus, M. (2019). Generasi Z sebagai Generasi Wirausaha. https://doi.org/10.31227/osf.io/4m7kz

Purnomo, A., Putri, R. A., \& Rosyidah, E. (2017). Kamus Manajemen Sumber Daya Manusia. Sidoarjo: UNUSIDA Press.

Ray, H. (2015). 5 Easy Steps to Successfully Launch an Educational Startup. Retrieved December 5, 2019, from https://www.designhill.com/designblog/easy-steps-to-successfully-launch-an-educational-startup/

Setyawati, I., Purnomo, A., Irawan, D. E., Tamyiz, M., \& Sutiksno, D. U. (2018). A Visual Trend of Literature on Ecopreneurship Research Overviewed within The Last two Decades. Journal of Entrepreneurship Education, 21(4), 1-7. Retrieved from https://www.abacademies.org/articles/a-visual-trend-ofliterature-on-ecopreneurship-research-overviewed-within-the-last-two-decades7468.html

Simarmata, J., Dharma, M., Putra Nasution, T., Manurung, R. T., Lubis, M. A., Kurniasih, N., ... Rahim, R. (2018). Prototype Application Multimedia Learning for Teaching Basic English. International Journal of Engineering \& Technology, 714(2), 264-266. https://doi.org/10.14419/ijet.v7i2.12.14689

Suci, S. H. A., Rosyidah, E., Asitah, N., Aini, N., Murni, A. W., Anam, F., ... Kuraesin, A. D. (2018). Learning from Picture and Picture Action Research: Enhancement of Counting Ability on Division of Numbers for Primary School Students. Journal of Physics: Conference Series, 1114(1), 012044. https://doi.org/10.1088/1742-6596/1114/1/012044

Sudrajat, D., Achdisty, M., Kurniasih, N., Roslina, Parwito, Mulyati, S., ... Sallu, S. (2019). The Implementation of Innovation in Educational Technology to Improve The Quality of Website Learning in Industrial Revolution Era 4.0 Using Waterfall Method. Journal of Physics: Conference Series, 1364, 012044. https://doi.org/10.1088/1742-6596/1364/1/012044 